\title{
Return to the road of capitalism: Recapitulating the post-socialist urban transition
}

\author{
MÁrton BERKI ${ }^{1}$
}

\begin{abstract}
Over the course of history, relatively slow and gradual processes of urbanisation are occasionally interrupted by periods of turbulent restructuring. The post-socialist transition is definitely one of the most outstanding examples of these changes, directly affecting the lives of over 300 million people. Within the confines of this succinct theoretical recapitulation, firstly, the relationship between capitalist and socialist urbanisation - as a broader conceptual frame - is presented, followed by the brief summary of the post-socialist transition's general characteristics. Subsequently, the specificities of the urban structure of socialist and post-socialist cities are subsumed, and finally, different scenarios and development perspectives for post-socialist cities are outlined.
\end{abstract}

Keywords: post-socialist cities, urban transition, urban theory, urban structure

\section{Introduction}

Over the course of history, relatively slow and gradual processes of urbanisation are occasionally interrupted by periods of turbulent restructuring, such as in the time of colonial endeavours, large conquests and wars, or in the case of transition to different political systems. Concerning the latter, the post-socialist transition is definitely one of the most outstanding examples from the recent past, directly affecting the lives of over 300 million people. Moreover, after the 2004 and 2007 enlargements of the European Union, the fate of post-socialist countries undoubtedly became a pan-European issue and responsibility.

On the one hand, there has been an increasing interest towards the political, economic and cultural restructuring of post-socialist cities from the side of the Western social sciences during the last two decades, particularly

\footnotetext{
${ }^{1}$ Department of Social and Economic Geography, Eötvös Loránd University, H-1117 Budapest, Pázmány Péter sétány 1/C; Institute for Sociology, Centre for Social Sciences, Hungarian Academy of Sciences, H-1014 Budapest, Országház u. 30. E-mail: berkimarton@yahoo.com
} 
due to the scholarly work of authors originating from (and later partly returning to) former socialist states, such as in the case of ANDRusz, G. et al. (1996), Bodnár, J. (2001), Herrschel, T. (2007), Stanilov, K. (2007), Czepczyński, M. (2008), or HiRT, S. (2012). Nevertheless, post-socialist urban theory still has a great number of question marks and dilemmas to be discussed.

Within the confines of this succinct theoretical recapitulation, in this paper firstly the relationship between capitalist and socialist urbanisation - as a broader conceptual frame - is presented, followed by a brief summary of the post-socialist transition. Subsequently, the specificities of the urban structure of socialist and post-socialist cities are subsumed, and finally, different scenarios and future development perspectives for post-socialist cities are outlined.

\section{The relationship between capitalist and socialist urbanisation}

In order to highlight the intricate relationship of capitalist and socialist urbanisation we turn back to SzELÉnYI's oft-cited question of 'How much difference did socialism make to urban development?' (SzELÉNYI, I. 1996). In response, he outlined two major intellectual strands.

According to the 'ecological model' (adopted by e.g. van DEN BerG, L. et al. 1982; Wilson, F.D. 1983; ENYEDI, Gy. 1988), the $20^{\text {th }}$ century urbanisation was primarily fuelled by rapid modernisation and industrialisation, and since socialist and contemporary capitalist states were both influenced by these processes, the similarities between capitalist and socialist cities overweighed their differences. In this view, these two types of cities represented nothing more than different variants of the general model of industry-led $20^{\text {th }}$ century urbanisation, and consequently, socialist cities were supposed to be characterised by the same urban development stages as the ones in capitalist settings, although with a temporal lag. Therefore, socialist cities should have also undergone the well-known path of urbanisation, suburbanisation, deurbanisation and reurbanisation, the only difference would be that the prevailing ideology of socialist states might have been able to filter some of the global impacts, possibly leading to the temporal prolongation of the stages.

As opposed to this reasoning, proponents of the so-called 'historical school' harshly criticised the social-Darwinist underpinnings of the process of urbanisation. In contrast to the above-mentioned presuppositions, they rather focused on the marked differences in the dominant mode of production on the one hand (neo-Marxist approach, see Harvey, D. 1973; Castells, M. 1977), and in sociopolitical organisation on the other hand (neo-Weberian approach, see PAHL, R. 1970; SzelÉNYI, I. 1996). According to this stance, their fundamental dissimilarity resulted in two distinct - capitalist and socialist - urbanisation models, as well as in the form of strikingly different socialist and capitalist cities. The most essential conceptual distinction between the two approaches is presented in Figure 1. 

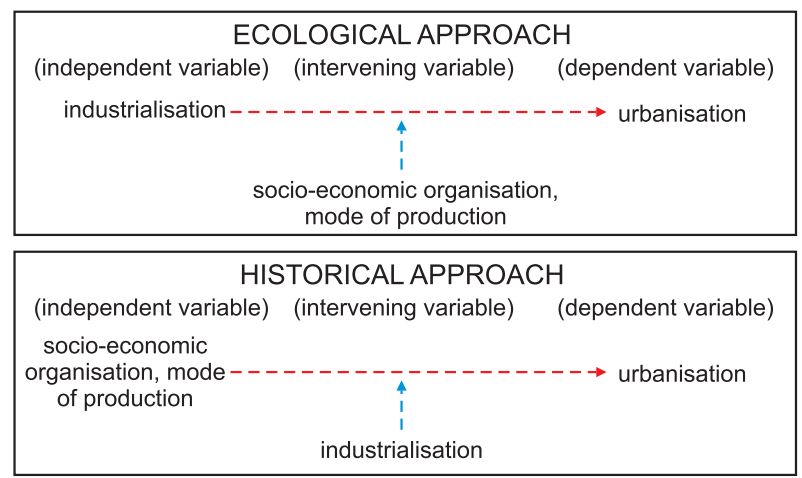

Fig. 1. Ecological and historical explanations of the process of urbanisation. Source: after SzelÉNYI, I. 1996, modified by the author

Since the socialist regimes established after World War II were slightly different from country to country, the changes in the scope of urbanisation - contrary to the common direction - were also manifested in diverse ways and at various paces. As a consequence, countries of the Eastern Bloc were characterised by highly different degrees of urbanisation throughout the decades of socialism; some of them (such as Romania, Bulgaria and especially the Soviet Union) were rapidly and heavily urbanising, others (for example East Germany and Hungary) to a lesser extent, whereas countries of the Balkan (e.g. Albania) preserved their predominantly rural character.

Recognising these remarkable differences, MusiL, J. (1980, p. 148) proposed a three-component analytical frame for the investigation of the socialistera urbanisation processes; in this model, he attempted to distinguish the 'permanent, common features' of socialist urbanisation (stemming from systemic determinations), the 'specific features' of urbanisation caused by the inherited differences in settlement structure and demographic situation, and finally, the differences resulting from the 'different phases of industrialisation and urbanisation'. Correspondingly, SzeLÉNYI (1993) also raised a similar question: How much of the distinct nature of socialist urbanisation was determined solely by the socialist system, and to what extent was it the consequence of the Central and Eastern European region's semi-peripheral capitalist past? According to Bodnár, J. (2001, p. 23), Western theorists mostly tend to ignore the latter historical legacy of the macro-region and perfunctorily subsume all specificities (always being understood as divergence from Western European and North American patterns) under the all-encompassing label of socialism.

Taking all these important differences into consideration, another remarkable (macro-scale) analytical frame emerged, that of the world-systems analysis, placing the Central and Eastern European region within the global 
power hierarchy of core countries, semi-peripheries and peripheries. An early example of this perspective can be traced in the comprehensive volume of Berend, T.I. and RÁNKI, Gy. (1976) but later, a more explicitly Wallersteinian reasoning is featured in the investigation of KENNEDy and SMITH (1989), or as recently as in the analyses of Melegh, A. (2006) or Bohle, D. and Greskovits, B. (2012). Besides this specific research tradition, the Regulation School's work on Fordist and post-Fordist capital accumulation regimes has also been applied in the case of the socialist (and later, post-socialist) context, and therefore, can be directly linked to the debate on the distinct or similar nature of socialist and capitalist urbanisation (see for example Altvater, E. 1993; Smith, A. and Swain, A. 1998; Chavance, B. 1994, 2002). As an important aspect of the topic, most of these analyses demonstrated that the rigid socialist half-Fordist accumulation regime was in many respects different from Western Fordist accumulation regimes characterised by more sophisticated and flexible modes of social regulation. Finally, a growing number of authors aim to establish theoretical links between modern (capitalist/socialist) and postmodern (and its specific variant, post-socialist) societies and urban development (e.g. KHARKHORDIN, O. 1997; Wu, F. 2003; HirT, S. 2012).

One of the recent contributions to the debate is provided in the theoretical framework elaborated by Gentile, M. et al. (2012). On the one hand, their approach also shifts away from the dialectical straightjacket of the capitalism-socialism binary, yet they still explain urbanisation processes in a dichotomic manner. In their model, two idealised city types - the homopolis and the heteropolis - are introduced, along with the complex processes these urban forms are created (and shaped) by, labelled as homopolitanisation and heteropolitanisation. While the distinction of socialist and capitalist cities is of an ideological, political and economic nature, the homopolis-heteropolis theoretical construct is based on their different social and spatial structures (irrespective of the underlying political and economic systems).

During state socialism, cities (as centres) played a key role in the formation of the new society; as part of this endeavour, eliminating differences was of paramount importance, which eventually led to social, economic and spatial homogenisation, and thus, to homopolitanisation. Nonetheless, it is important to note that homopolises could be found out of the Eastern Bloc as well (such as the coal-mining town of Gelsenkirchen, Detroit and Flint, both being based on motor industry, or post-war Charleroi and Liège). In addition, several principles of socialist urban planning - including architectural modernism or the idea of neighbourhood units - were also inherently Western (before having been purified by the ideological filter of socialist central authorities).

Since these global influences were no more restricted after 1990, an extremely rapid heteropolitanisation began in Central and Eastern European cities. The result of these transformation processes is the formation of the 
heteropolis, the socially and spatially complex and heterogeneous city, characterised by a high level of diversity and flexibility, as well as by a decentralized (or even fully laissez-faire) regulatory environment.

To sum up, in the light of the diverse conceptualisations and disputes outlined in this section, it is evident that the intriguing intellectual debate on the nature of capitalist and/or socialist urbanisation spanning from the 1970s is still far from being closed.

\section{General characteristics of the post-socialist transition}

According to the apt phrasing of SýкоRA, L. (2009, p. 387.), the post-socialist transition is ' $[a]$ broad, complex, and lengthy process of societal change starting with the refusal of communist regimes and central planning, leading to democratic political regimes and a market economy'. In terms of urbanism, this epoch might also be understood as a period of restructuring through which cities gradually lose their former socialist specificities and turn - or, more pertinently - return to the road of capitalist urban development. Hence, post-socialist cities reflect temporary conditions, the dynamically evolving adaptation of the inherited socialist urban environment to the capitalist rules of the game, i.e. to the new political and economic circumstances.

The transition consists of a set of transformation processes, either initiated by the central governments (such as in the case of the initial political and economic reorientation), or spontaneously emerged due to the altered conditions (for instance in the case of the citizens' changing savings strategies or cultural habits). Nevertheless, it is important to underline that the process of the transition and the (re-)building of capitalism took place in a highly uneven manner in the former Eastern Bloc, both spatially and temporally. Just as capitalism is not a uniform construct (see in the works of, among others, Esping-Andersen, G. 1990; HAll, P.A. and Soskice, D. 2001), so too was not its dialectical counterpoint, socialism, and certainly its successor, post-socialism either (see e.g. Fassmann, H. 1997; Greskovits, B. 2004).

Applying a Foucauldian perspective for historical enquiry, it is always more challenging to focus on breaking points instead of continuity and linearity (Foucault, M. 2002). In this regard, one of the most essential questions raised in the extensive literature dealing with the relationship of socialism and postsocialism (such as in Andrusz, G. et al. 1996; Verdery, K. 1996; Fraser, N. 1997; Burawoy, M. and Verdery, K. 1999) is whether there was a sudden and sharp break between the two epochs (i.e. an immediate and complete reckoning with the communist past), or rather a smooth and more gradual process of transition? Since these systemic changes can never be uniformly conceptualised (either as a breaking point or as an organic process), the answer usually varies depending on 
which aspects - i.e. the political, economic, cultural, demographic etc. dimensions - of the transition are being scrutinised. (Concerning the issue of temporal continuities and/or discontinuities, see the recent work of Grubbauer, M. 2012.)

Therefore, the most important aspect for the understanding of postsocialist urban change undoubtedly lies in its temporally multi-layered nature. According to SÝKORA (2009), firstly a short-term period can be outlined when the fundamental principles of political and economic organisation are reshaped (i.e. political parties and local municipalities are established, democratic elections are held, the legal frames of market economy are implemented etc.). These changes might be realised even within a few months, usually in a topdown manner. In contrast, the mid-term period might last much longer, during which peoples' habits and norms are adapted to new political, economic and cultural environment: while socialism was organised along collective values these former(ly conditioned) norms slowly started to changed after 1990, depending on the intensity of global influences. The length of this transition might last up to 10-15 years in the case of certain social groups, however, in the end, the majority of post-socialist societies are also characterised by individualism, hedonism, the need of self-expression, and hybrid consumption. Finally, right from 1990, a long-term period also begins in which the stable patterns of urban morphology and land use are being reshaped. (These fundamental changes may take several decades.)

Still concerning the theorisation of the post-socialist transition, further complications are caused by its two-level nature. On the one hand, there is a local, post-socialist transition (from state socialism to market economy) but, parallel to this, there are also several global political, economic and cultural shifts that influence local contexts (such as the restructuring of the Fordist, Keynesian welfare state to a post-Fordist, post-Keynesian neoliberal state). Importantly, these two levels of transition are mutually interrelated and interdependent, both strengthening and weakening each other (SÝкORA, L. 2009). Therefore, albeit post-1990 changes might seem internal, they are in fact deeply embedded in contemporary global processes. Consequently, when investigating the urban development trends of Central and Eastern Europe, it cannot be unequivocally assessed whether a given phenomena is the result of the post-socialist transition or that of the global restructuring (or, possibly, the particular hybridisation of the two).

Regarding global post-Fordist and post-Keynesian transformations, it is important to emphasise that Western European and North American societies have also undergone these processes, however, much earlier (during the 1960s and 1970s) and in a more gradual way. Therefore, Western policy-makers had more time to 'test' different development concepts and, if necessary, to mitigate their negative impacts. In contrast to the Western context, Central and Eastern European transition countries quickly adopted the laissez-faire model of social (and also urban) development, partly as an antidote to their totalitarian past 
(Stanilov, K. 2007). During the post-socialist transition, national and urban governance is increasingly influenced by the neoliberal doctrine, which was initially - as a specific socialist legacy - blended with the institutions of the welfare state (SÝKORA, L. 2009).

Over the past years, however, this specificity has also been changed, since state planning (and, as its part, urban and regional planning) is widely considered as being opposed to the needs of the market. As a result, the privileged group of socialist-era urban planners are replaced by investors, playing a key role in influencing the political sphere as well. Due to the overall decline in planning, uncoordinated development concepts and ad hoc decisions are becoming more and more frequent. Moreover, after the 2004 enlargement of the European Union, the (mostly uncritical) mimicry of Western practices also becomes widespread in the region.

Since the access to foreign direct investment (FDI) turned out to be one of the main differentiating factors of economic prosperity after 1990, the appearance of multinational companies and the growing importance of international institutions significantly reshaped local economies. As a result of the ex-socialist countries' entry into the global competition, several new actors gained the power to influence the cityscape, leading to a high-level urban fragmentation (Gentile, M. et al. 2012). Besides that, the process of rapid and incautious privatisation - considered as the leitmotif of the post-socialist period by BoDNÁr (2001) - also greatly contributed to the fragmentation of urban space (see also in Grime, K. 1999). The extraordinary scope and impact of privatisation is reflected in the private homeownership rates of several Central and Eastern European countries being around 90 percent, especially when compared to the mere 67 percent of the United States, the so-called 'nation of homeowners' (HirT, S. 2012, p. 44).

Finally, even though it might be less evident but the transition had indirect demographic consequences as well. The main political aim of the socialist leadership, at least at the level of official propaganda, was the creation of a (more) just society, which was to be achieved - besides collectivisation - by the state-controlled allocation of housing (SÝкоRA, L. 2009). As a result, the official marriages and the compulsory childbearing required for these subsidies both contributed to the survival of the tradition family model, and also 'protected' socialist countries against the alarming demographic trends of Western societies. Although these need-based housing policy principles would have triggered social homogeneity, however, in practice, the (re-)allocation of housing rather depended on political merits, party membership etc. To conclude, the spatial stratification and segregation patterns of socialist cities were not only affected by macro-structures but also by the decisions of individual agents connected to childbearing, party membership, political engagement and so forth (Gentile, M. et al. 2012). 
Based on the above-discussed considerations, the post-socialist transition definitely caused elementary changes in the affected societies. From the perspective of over two decades, we might assert that the first years of the transformation fulfilled the grim prediction of John Maynard KeYNEs from 1933, according to whom 'a transition will involve so much pure destruction of wealth that the new state of affairs will be, at first, far worse than the old' (cited in HiRT, S. 2012, p. 40). Correspondingly, countries of the former Eastern Bloc were characterised by a sudden decrease of GDP, peaking unemployment, unleashed inflation, and re-emerged ethnic conflicts in the first half of the 1990s. The level of social polarisation rapidly increased, both between and within countries, as well as between and within cities. Although later, around the turn of the millennia, the first signs of economic recovery already appeared but the acute social problems still remained, and the economic growth of Central and Eastern European countries was disrupted by the recession of the past years.

\section{The specificities of the urban structure of socialist and post-socialist cities}

When taking stock of the literature dealing with the period of socialism and post-socialism, STANILOv, K. (2007) highlights that the majority of works primarily focused on the economic and political aspects of the transition, while relatively little attention has been paid to urban structure analyses to date. The rare exceptions include the general model of SýKORA (2009) as well as a number of post-1990 case studies (e.g. CsanÁdi, G. and LadÁNYI, J. 1992; or Dingsdale, A. 1999, for Budapest; SýKORA, L. 1999, for Prague). The main conclusion of these investigations was that state socialism (lasting for over four decades) created several common characteristics in Central and Eastern European cities which markedly - both morphologically and aesthetically - distinguished them from the capitalist cities of the same era.

Generally speaking, socialist cities were scrupulously planned, characterised by uniformity and the lack of spontaneity (HamiLton, F.E.I. 1979). However, as the most important morphological difference between the two types, they were significantly denser and more compact, especially when compared to the sprawling North American metropolises. This difference can be traced back to the preceding capitalist - and in some places even medieval - built environment of the cities. Since these legacies could not be easily removed or eliminated, the socialist power concentrated on new constructions (mostly multi-storey prefabricated buildings) at the edge of the cities on the one hand, and on infill developments on the other hand (SÝ́KORA, L. 2009).

Furthermore, as another significant dissimilarity, their inner city neighbourhoods were surrounded by vast housing estates. Hence, in contrast to the North American metropolis, the verticality of the socialist city was growing 
from the centre to its edges (using the terminology of GentiLe, M. et al. 2012, 293., 'hollow' cities were created). Nevertheless, contrary to their otherwise compact form, in other regards, socialist planning was indeed generous with urban space: throughout the entire Eastern Bloc, enormous parade squares and monumental representative buildings have been erected in the reshaped historical inner city areas (such as the Procession Square in Budapest or the Palace of Parliament in Bucharest). With the transition, completely opposite processes began, since contemporary post-socialist cities are rather characterised by shrinking public spaces and expanding private ones (HIRT, S. 2012).

Along with the subordinated role of services, the economy of the socialist city was dominated by industry (both in terms of employment and land use). One of the underlying ideological reasons of this one-sided economic structure was to keep manual workers (as a revolutionary force) in major cities (SÝ́коRA, L. 2009). This strong industrial character was, however, coupled with a generally weak retail supply even during the last years of state socialism: according to Tosics, I. (2005), in the early 1990s retail space per person was three times lower in Moscow than in Berlin. Urban services, such as hospitals, schools and cultural institutions were planned in a hierarchical manner, based on the economies of scale. For a better accessibility of public services, socialist cities heavily relied on mass transportation: whereas $80-90$ percent of urban trips were carried out by mass transit in the late 1980s, this proportion decreased to only 50 percent by now, while private car ownership nearly tripled in the region (HIRT, S. 2012, p. 44).

Socialist cities were not only different from their Western counterparts in terms of their spatial patterns and morphology but also regarding their social character: they were characterised by lower levels of diversity, segregation, marginality and informality, and in general - due to the permanent surveillance by the authorities - they were 'safer' as well (HIRT, S. 2012).

Remarkably, most of the pre-socialist patterns of residential differentiation re-emerged during the transition, while new enclaves also appeared in these cities. After 1990, however, not only the level of socio-spatial disparities and the stratification of societies increased but the social groups' mobility as well, even though the main directions of migration dynamically changed. In the first period, during the 1990s, the least prosperous urban areas (primarily run-down inner city neighbourhoods and large housing estates) were affected by a selective out-migration of younger and higher qualified inhabitants (usually moving to the suburbs). This was, in the majority of ex-socialist countries, followed by the re-appreciation of inner city areas from the 2000s, through contradictory gentrification processes leading to the exclusion of less affluent social groups. Finally, and most recently, another kind of migration is fuelled by the economic crisis of the past years in Central and Eastern Europe: besides the younger generations' flow to Western Europe (and partly to North America), 


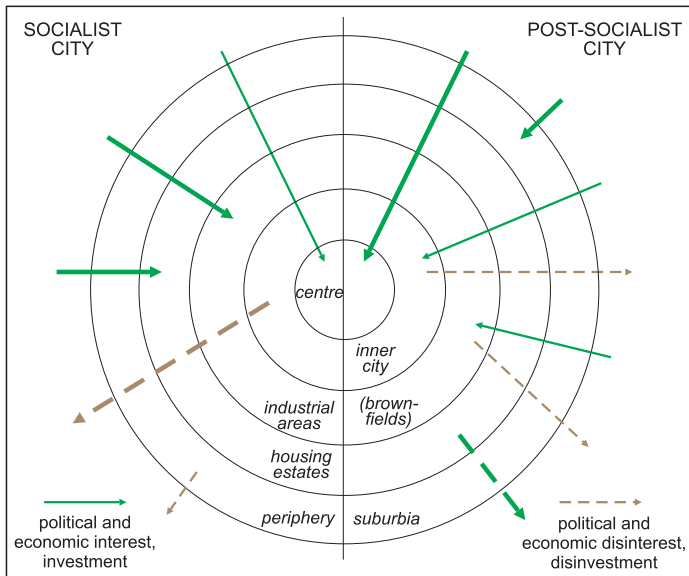

Fig. 2. Changing political and economic interests in socialist and post-socialist cities. Source: after SýkoRA, L. 2009, modified by the author more and more low income urban residents tend to move to countryside areas as part of their daily survival strategies.

Beyond the general characteristics of the morphological, functional and social transformation of socialist cities, it might also be beneficial to review the changing pre- and post-1990 roles and power positions of different urban zones. Hereinafter, a concise overview of these changes will be provided, based on the extension of the comparative model of SýKorA (2009) (Figure 2).

\section{The city centre and the inner city}

In the socialist period, besides residential properties, the cities' central cores and inner areas were characterised by representative governmental and municipal buildings, as well as by public institutions responsible for the residents' ideological education (such as cultural centres or libraries), as a sharp contrast to business-driven Western architecture. At the same time, however, inner cities were also treated as the hideout of the bourgeoisie, stigmatised as reactionists and considered as the enemies of the state. As a consequence, in some inner city areas even damages from World War II remained untouched for decades. Due to their gradual deterioration, radical inner city reformulations were carried out from the 1970s. (Thus, from today's perspective, areas which remained intact and neglected owing to the indifference of state authority might be regarded as much more fortunate ones.) Urban regeneration endeavours aimed at the refurbishment of central residential neighbourhoods were only initiated as late as in the 1980s, primarily in the form of cautious attempts and smaller-scale experiments (SÝKORA, L. 2009).

After 1990, the fate of city centres and inner residential areas was rather diverse. In some of the post-socialist metropolises, American and Eastern Asianstyle central business districts emerged with high-rise architecture (e.g. in Moscow, Warsaw or Belgrade), whereas in other cities, the main emphasis was instead placed on the conservation and/or rehabilitation of historical urban areas (such as 
in Prague or Budapest), although with a particular attention to the needs of mass tourism (Stanilov, K. 2007). In addition, large-scale urban revitalisation investments were in many cases not fully controlled or steered by local municipalities but by international capital; therefore, such ventures were rarely tailored to the requirements of local residents. As a result of the so-called 'spotlight renovation' practices (affecting only relatively small areas), post-socialist city centres and inner city districts are still Janus-faced; youthful and rapidly gentrifying neighbourhoods create striking contrasts with the ageing, blighted urban quarters.

\section{The former industrial areas}

Industrial areas - originally established and developed on the edge of cities in the late $19^{\text {th }}$ century - were of paramount importance for the newly settled socialist leadership; thus, due to the commonly believed primacy of industrial production, these areas immediately fell in the hands of the state through nationalisation. Along with the massive ring of new housing estates, monofunctional industrial districts became the central authorities' most favoured and supported urban zones. However, while the process of deindustrialisation set into motion in the advanced capitalist countries already in the 1960s and 1970s, the cities of the Eastern Bloc - owing to the secure hinterland of the COMECON-market and the Soviet Union - were not affected by these changes. Under the aegis of the inflexible central planning, the vast majority of the large state-owned industrial enterprises were artificially maintained for political and legitimating reasons until as late as 1990; as a result, cities of state-socialism did not undergo the far-reaching post-Fordist transformation processes typical for the Western capitalist economies.

Central and Eastern European cities, however, paid a high price for these state interventions, as the extremely rapid deindustrialisation processes starting right after 1990 had more serious consequences in the region compared to the West. Due to robust restructuring the economy of post-socialist cities rapidly shifted from manufacturing to the tertiary sector in the early 1990s. As a result, similarly to the inner city neighbourhoods, the contemporary character of the former industrial areas is also highly ambiguous; in this case, a relatively low number of successful brownfield regeneration projects can be found against vast areas of derelict industrial land still incapable for renewal.

\section{The socialist housing estates}

Besides the damage wrought by World War II, the most radical intervention in the urban tissue of Central and Eastern European cities during the entire $20^{\text {th }}$ 
century was undoubtedly caused by the mass-scale construction of socialist housing estates. The devastation of the war and the subsequent baby boom together resulted in an acute housing shortage which also closely coincided with the ideological and urban development endeavours of the newly established socialist regime aiming at creating a new society with an entirely new (socialist) way of life. The construction of housing estates began on the extensive empty (in today's terminology, 'greenfield') areas then abundantly available around the cities' industrial districts, and indeed, this form of (mass-)housing initially provided decent living conditions for the newcomers, especially for low-skilled industrial workers.

After 1990, housing estates became the biggest losers of post-socialist transition, partly due to their outdated technological solutions, and partly as a consequence of the rapid ageing processes caused by selective outmigration. As a consequence, a significant number of socialist-era housing estates are still facing complex societal challenges (see Csizmady, A. 2003). Therefore, while socialist regimes concentrated on the empty areas located on the urban fringe in order to establish mass-scale housing and large industrial conglomerates, post-socialist urban development - mainly due to the newly emerging suburbanisation processes - stretches far beyond the administrative borders of the former socialist city. According to Stanilov (2007), the post-1990 urban growth simply 'leaped' over the immovable ring of housing estates, once representing the quintessence of socialist urban planning. Nevertheless, despite the massive outmigration from these areas, a significant share of the population in post-socialist cities still resides in large housing estates (e.g. $82 \%$ of the total population in Bucharest, $77 \%$ in Bratislava, $60 \%$ in Sofia, $56 \%$ in Warsaw, and 55\% in Tallinn) (Hirt, S. 2012, p. 35).

\section{The former periphery - The contemporary suburbia}

Socialist cities preserved their compact character, they were not girdled with a vast, sprawling suburban zone. Large neighbourhoods of detached houses were not desirable for the socialist regime, since this form of housing would have provided residents with too much private space, possibly contributing to a capitalist-type of residential segregation (according to these opinions, as cited by Hirt, S. 2012, p. 40, 'it is the yard that makes the bourgeois'). Consequently, in contrast to the extensive American suburbia, socialist cities were mainly surrounded by agricultural land, occasionally dotted with industrial new towns (SzIrmai, V. 1988) established after World War II. During this period, large cities (as central places) represented the apex of the redistributive system, whereas the adjacent areas were primarily considered as their periphery, in many cases having been suppressed via administrative tools as well. 


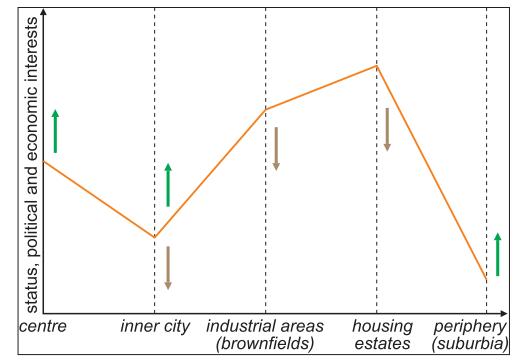

Fig. 3. The changing political and economic status of socialist urban areas during the post-socialist transition. Source: after SÝKORA, L. 2009, modified by the author

Hence, the massive outflow of urban population and the rise of suburban areas began only after 1990. This process was further accelerated by the liberalisation of the real estate market and a booming private car ownership. In spite of the negative environmental impacts of urban sprawl, residential flows were soon followed by the suburbanisation of the industry and - to a lesser extent - the services sector as well. As a result, along with city centres, the formerly neglected and peripheral suburban areas became undoubtedly the most dynamically developing areas of contemporary post-socialist agglomerations.

As shown by Figure 3, the overall status of the different urban zones, as well as the political and economic interests related to these areas have both undergone a significant realignment in post-socialist cities after 1990, mainly heading towards a completely opposite direction compared to pre-transition processes and power relations (SÝKORA, L. 2009). Areas previously preferred by the communist regimes immediately lost their privileged positions, whereas the ones that were less supported - for ideological reasons - became the most prosperous areas of recent years. To conclude, this intra-urban equilibration process might be referred to as 'the paradox of post-socialist transition'.

\section{Future perspectives of post-socialist cities}

The dissolution of the Soviet Union and the collapse of state-socialism caused overwhelming changes in East Central Europe. Stanilov (2007) identifies it as a global-scale Pruitt-Igoe, the most remarkable moment of the dawn of modernity. Concerning epochal demarcations, HiRT (2012) draws similar parallels when comparing the era of socialism and post-socialism with the binary of modernity and post-modernity, highlighting the apparent similarities between post-modern and post-socialist urbanism.

Concerning the future perspectives of post-socialist cities, the most comprehensive overview is provided by Kiril StaniLov (2007), who outlines four possible development scenarios based on macro-regional urbanisation trends.

(1) In the long term, he sees the possibility of a West European-type development, characterised by controlled rates of suburbanisation, vibrant central and inner city areas, high quality public services, and noticeable (although not excessive) patterns of social stratification. 
(2) In contrast, the North American model is rather dominated by higher levels of privatisation and spatial deconcentration, as well as a stronger segregation by income and ethnicity.

(3) Thirdly, an East Asian-type of urban development path might be characterised by the coexistence of an exceptionally rapid economic growth and strong local cultural traditions.

(4) Finally, he also warns about the possible emergence of a fourth kind of (over-, or dependent) urbanisation typical of Third World countries. This model is characterised by an uncontrollable rate of population growth exceeding the ability of the economy and the government to provide jobs and an appropriate urban infrastructure, consequently leading to increasing urban informality.

Thus far, according to STANILOV, post-socialist urban development exhibits select features of these models. Over the past 10-15 years, the vitality of inner city neighbourhoods has undoubtedly grown (in correspondence with the Western European model), while the unleashed suburbanisation, the growing fascination with (mass-)consumer culture, and the all-encompassing privatisation processes rather resemble the North American development path. Until the recession of 2008, several Central and Eastern European regions and cities were characterised by East Asian-type 'booming' economies, however, as an alarming signal of the fourth model, the rapid erosion of public service provision can also be observed in post-socialist cities. Beyond all these urban development processes, the increasing level of socio-economic polarisation is definitely one of the most enduring aspects of the so-called 'bifurcated transition' (HirT, S. 2012), i.e. the simultaneous appearance and coexistence of First World-style and Third World-style capitalisms.

In whichever direction the urbanisation processes of transition countries may eventually turn, it is obvious that the inhabitants of post-socialist cities still have to face several local and global challenges. Within the ex-socialist countries joining the European Union in 2004 and 2007, according to the statement of a 2008 World Bank report, even though "the transition is over, but the Schumpeterian process of creative destruction is not" (Alam, A. et al., 2008, p. 29).

\section{REFERENCES}

Alam, A., Casero, P.A., Khan, F. and Udomsaph, C. 2008. Unleashing Prosperity. Productivity Growth in Eastern Europe and the Former Soviet Union. Washington D.C., World Bank, $274 \mathrm{p}$.

Altvater, E. 1993. The Future of the Market. An Essay on the Regulation of Money and Nature after the Collapse of "Actually Existing Socialism". London, Verso, 272 p.

Andrusz, G., Harloe, M. and Szelényi, I. Eds. 1996. Cities After Socialism. Urban and Regional Change and Conflict in Post-Socialist Societies. Oxford, Blackwell, 356 p. 
Berend. T.I. and RÁNKI, Gy. 1976. Közép-Kelet-Európa gazdasági fejlödése a 19-20. században (The Economic Development of Central and Eastern Europe during the $19^{\text {th }}$ and $20^{\text {th }}$ Century). Budapest, Közgazdasági és Jogi Könyvkiadó, 723 p.

Bodnár, J. 2001. Fin de Millénaire Budapest. Metamorphoses of Urban Life. Minneapolis, University of Minnesota Press, 222 p.

Bohle, D. and Greskovits, B. 2012. Capitalist Diversity in Europe's Periphery. New York, Cornell University Press, 304 p.

Burawoy, M. and Verdery, K. Eds. 1999. Uncertain Transition. Ethnographies of Change in the Postsocialist World. Lanham MD, Rowman \& Littlefield, 322 p.

Castells, M. 1977. The Urban Question. London, Edward Arnold, 502 p.

Chavance, B. 1994. The Transformation of Communist Systems. Economic Reform since the 1950s. Boulder, Westview, $225 \mathrm{p}$.

Chavance, B. 2002. Institutions, Régulation and Crisis in Socialist Economies. In Régulation Theory. Eds. Boyer, R. and SAIllard, Y., Paris, La Découverte, 267-273.

CsanÁdi, G. and LADÁNYI, J. 1992. Budapest térbeni-társadalmi szerkezetének változásai (Changes in the Socio-Spatial Structure of Budapest). Budapest, Akadémiai Kiadó, 159 p.

Csizmady, A. 2003. A lakótelep (The Housing Estate). Budapest, Gondolat Kiadó, 320 p.

Czepczyński, M. 2008. Cultural Landscapes of Post-Socialist Cities. Representation of Powers and Needs. Aldershot, Ashgate, 209 p.

Dingsdale, A. 1999. Budapest's Built Environment in Transition. GeoJournal 49. (1): 63-78.

ENYEDI, Gy. 1988. A városnövekedés szakaszai (Stages of Urban Growth). Budapest, Akadémiai Kiadó, 115 p.

Esping-Andersen, G. 1990. The Three Worlds of Welfare Capitalism. Princeton, Princeton University Press, $264 \mathrm{p}$.

Fassmann, H. 1997. Regionale Transformationsforschung. Theoretische Begründung und empirische Beispiele. In Regionale Transformationsprozesse in Europa. Beiträge zur Regionalen Geographie (44). Hg. MAYr, A., Leipzig, Institut für Länderkunde, 30-47.

Foucault, M. 2002. The Archaeology of Knowledge. London, Routledge, 275 p.

Fraser, N. 1997. Justice Interruptus. Critical Reflections on the "Postsocialist" Condition. London, Routledge, $241 \mathrm{p}$.

Gentile, M., Tammaru, T. and van Kempen, R. 2012. Heteropolitanization. Social and Spatial Change in Central and East European Cities (Guest Editorial). Cities 29. (5): 291-299.

Greskovits, B. 2004. Beyond Transition. The Variety of Post-Socialist Development. In From Liberal Values to Democratic Transition. Ed. Dworkin, R.W., Budapest, Central European University Press, 201-225.

Grime, K. 1999. The Role of Privatisation in Post-Socialist Urban Transition. Budapest, Kraków, Prague and Warsaw. GeoJournal 49. (1): 35-42.

Grubbauer, M. 2012. Toward a More Comprehensive Notion of Urban Change. Linking PostSocialist Urbanism and Urban Theory. In Chasing Warsaw. Socio-Material Dynamics of Urban Change since 1990. Eds. Grubbauer, M. and Kusiak, J., Frankfurt, Campus, 35-60.

Hall, P.A. and Soskice, D. 2001. Varieties of Capitalism. The Institutional Foundations of Comparative Advantage. Oxford, Oxford University Press, 540 p.

Hamilton, F.E.I. 1979. Spatial Structure in East European Cities. In The Socialist City. Spatial Structure and Urban Policy. Eds. French, R.A. and Hamilton, F.E.I., Chichester, West Sussex, John Wiley \& Sons, 195-261.

Harvey, D. 1973. Social Justice and the City. London, Edward Arnold, 336 p.

Herrschel, T. 2007. Global Geographies of Post-Socialist Transition. Geographies, Societies, Policies. London, Routledge, 288 p. 
Hirt, S. 2012. Iron Curtains. Gates, Suburbs and Privatization of Space in the Post-Socialist City. Chichester, West Sussex, John Wiley \& Sons, 256 p.

Kennedy, M. and Smith, D.A. 1989. East-Central European Urbanization. A Political Economy of the World-System Perspective. International Journal of Urban and Regional Research 13. (4): 597-624.

Kharkhordin, O. 1997. Reveal and Dissimulate. A Genealogy of Private Life in Russia. In Public and Private in Theory and Practice. Perspectives on a Grand Dichotomy. Eds. Weintraub, J. and Kumar, K., Chicago, University of Chicago Press, 333-363.

Melegh, A. 2006. On the East/West Slope: Globalization, Nationalism, Racism and Discourses on Central and Eastern Europe. Budapest, Central European University Press, 220 p.

MusiL, J. 1980. Urbanization in Socialist Countries. Armonk NY, M.E. Sharpe, 185 p.

PAHL, R.E. 1970. Whose City? London, Longman, 273 p.

Smith, A. and Swain, A. 1998. Regulating and Institutionalising Capitalisms. The MicroFoundations of Transformation in Eastern and Central Europe. In Theorising Transition. The Political Economy of Post-Communist Transformations. Eds. Pickles, J. and Sмітн, A., London-New York, Routledge, 25-53.

Stanilov, K. Ed. 2007. The Post-Socialist City. Urban Form and Space Transformations in Central and Eastern Europe after Socialism. Dordrecht, Springer, $506 \mathrm{p}$.

Sýkora, L. 1999. Changes in the Internal Spatial Structure of Post-Communist Prague. GeoJournal 49. (1): 79-89.

Sý́ora, L. 2009. Post-Socialist Cities. In International Encyclopedia of Human Geography (Volume 8). Eds. Kitchin, R. and Thrift, N., Oxford: Elsevier, 387-395.

Szelényi, I. 1993. East European Socialist Cities. How Different Are They? In Urban Anthropology in China. Eds. Guldin, G. and Southall, A., Leiden, E. J. Brill, 41-64.

Szelényi, I. 1996. Cities under Socialism - and After. In Cities After Socialism. Urban and Regional Change and Conflict in Post-Socialist Societies. Eds. Andrusz, G., Harloe, M. and SzelénYI, I., Oxford, Blackwell Publishers, 286-317.

Szirmai, V. 1988. "Csinált" városok ("Made" Cities). Budapest, Magvető Kiadó, 239 p.

Tosics, I. 2005. Post-Socialist Budapest. The Invasion of Market Forces and the Response of Public Leadership. In Transformation of Cities in Central and Eastern Europe. Towards Globalization. Eds. Hamilton, F.E.I., Dimitrowska Andrews, K. and PichlerMilanovic, N., Tokyo: United Nations University Press, 248-280.

Van den Berg, L., Drewett, R., KlaAssen, L., Rossi, L. and Vijverberg, C. 1982. Urban Europe (Volume 1). A Study of Growth and Decline. Oxford, Pegasus, 162 p.

Verdery, K. 1996. What Was Socialism, and What Comes Next? Princeton, Princeton University Press, 298 p.

Wilson, F.D. 1983. Contemporary Patterns of Urbanization. Madison, Center for Demography and Ecology, University of Wisconsin, $157 \mathrm{p}$.

Wu, F. 2003. Transitional Cities (Commentary). Environment and Planning A. 35. (8): 1331-1338. 